p-ISSN: 2503-1392

e-ISSN: $2620-5424$

\title{
FAKTOR - FAKTOR YANG BERHUBUNGAN DENGAN KEIKUTSERTAAN IBU HAMIL DALAM MELAKUKAN SENAM HAMIL PADA KELAS IBU HAMIL
}

\section{FACTORS RELATING TO THE PARTICIPATION OF PREGNANT MOTHERS IN DOING PREGNANT EFFECT ON PREGNANT MOTHER CLASSES}

\author{
Maria septiana \\ Akademi Kebidanan Budi Mulia Prabumulih, Jl. Jend. Sudirman No 004 RT 01 RW 01 Kel: Cambai, Kec: \\ Cambai \\ email :maria.septiana@ rocketmail.com
}

\begin{abstract}
ABSTRAK
Senam hamilmerupakan latihan gerakan terapeutik untuk mempersiapkan wanita hamil, secara fisik atau mental, untuk menangani pengiriman cepat, aman dan spontan. Partisipasi ibu hamil dalam membuat senam hamil mungkin dipengaruhi oleh beberapa faktor seperti pengetahuan, pendidikan, dan pekerjaan ibu hamil. Penelitian ini untuk mengetahui pengaruh pengetahuan, pendidikan dan pekerjaan terhadap partisipasi ibu hamil untuk melakukan senam hamil. Penelitian observasional observasional dengan pendekatan cross sectional. Populasi penelitian adalah 40 wanita hamil. Total sampling diaplikasikan untuk mendapatkan 40 sampel. Analisis bivariat menggunakan uji chi-square dan analisis multivariat menggunakan regresi logistik yang diaplikasikan dalam analisis data. Hasil penelitian menunjukkan responden memiliki pengetahuan paling banyak sebesar 60\% kategori kurang baik, 67,5\% tingkat pendidikan dasar, 67,5\% ibu bekerja sebanyak, 55\% ibu hamil yang tidak mengikuti latihan kehamilan. Ada hubungan antara pengetahuan, pendidikan, pekerjaan dengan partisipasi ibu hamil di kelas yang melakukan latihan kehamilan pada ibu hamil ( $p=0,002, p=0,005$, $p=0,014)$. Ada pengaruh bersama pengetahuan $(p=0,048 ; \operatorname{Exp} B=5,196)$, pendidikan $(p=0,041 ; \operatorname{Exp} B=$ $7,272)$ dan pekerjaan ( $p=0,041$; Exp $B=6,201)$ partisipasi ibu hamil dalam melakukan senam kehamilan.
\end{abstract}

Kata kunci: Pengetahuan, Pendidikan, Pekerjaan, latihan kehamilan

\begin{abstract}
Pregnancy exercise is therapeutic motion exercises to prepare pregnant women, physically or mentally, to deal with the fast delivery, secure and spontaneous. The participation of pregnant women in making pregnancy exercise may be influenced by several factors such as knowledge, education, and employment of pregnant women. This study was to know the influence of knowledge, education, and employment on the participation of pregnant women for doing pregnancy exercise. This was an observational analytical study with a crosssectional approach. The study population was 40 pregnant women. Total sampling was applied to obtain 40 samples. Bivariate analysis using the chi-square test and multivariate analysis using logistic regression was applied in the data analysis. Results of the study showed respondents have the most knowledge at $60 \%$ unfavorable category, $67.5 \%$ the level of primary education, $67.5 \%$ as many working mothers, $55 \%$ pregnant women who do not follow pregnancy exercise. There is a relationship between knowledge, education, employment with the participation of pregnant women in the class doing pregnancy exercise on pregnant women $(p=0.002, p=0.005, p=0.014)$. There are influences together knowledge $(p=0.048 ; \operatorname{Exp} B=5.196)$, education $(p=0.041 ; \operatorname{Exp} B=7.272)$ and employment $(p=0.041 ; \operatorname{Exp} B=6.201)$ the participation of pregnant women in doing pregnancy exercise.
\end{abstract}

Keywords: Knowledge, Education, Employment, pregnancy exercise 


\section{PENDAHULUAN}

Senam hamil adalah terapi latihan gerak untuk mempersiapkan ibu hamil secara fisik ataupun mental untuk menghadapi persalinan yang cepat, aman dan spontan. Senam hamil pada dasarnya adalah pelatihan bagi wanita hamil sehat menyiapkan kondisi fisiknya, menjaga kondisi otot-ototnya dan persediaan yang berperan dalam proses dan mekanisme persalinan. Dalam hal ini otot-otot dinding perut, ligamen-ligamen, otot-otot dasar panggul dan sebagainya yang berhubungandengan proses persalinan (Andi. Maryunani, \& S, 2011. h. 29).

Kursus persiapan persalinan melalui senam hamil sebenarnya mengandung dua tujuan yaitu menyiapkan kondisi fisik dan psikis wanita hamil terutama dalam menumbuhkan sikap percaya diri dalam menghadapi persalinan. Wanita hamil harus mendapat pengertian mengenai proses kehamilan dan persalinan sehingga dapat menghadapi secara realistis dalam artinya hilangnya rasa takut dan cemas. Wanita hamil perlu diberikan pelatihan teknik relaksasi dan pernafasan untuk mengurangi rasa nyeri dan memperlancar persalinan. Rasa nyeri akan menyebabkan ibu bersalin menjadi stress sehingga akan meningkatkan pengeluaran hormone adrenalin yang menganggu sekresi hormon oxytocin pada lobus posterior hipofise sehingga akan menurunkan aktivitas uterus yang akan memperpanjang waktu persalinan (Putri, Shinta, 2014. h. 58).

Setiap ibu hamil hendaknya mengikuti senam hamil yang bermanfaat bagi ibu dan janin yang dikandungnya. Keikutsertaan ibu hamil dalam melakukan senam hamil menyangkut perilaku kesehatan ibu hamil. Menurut L. Green (Notoatmodjo, 2003. h. 113-117.), perilaku kesehatan seseorang atau masyarakat dipengaruhi oleh 2 faktor pokok, yakni faktor perilaku (behavior causes) dan faktor di luar perilaku (nonbehavior causes). Perilaku itu sendiri ditentukan atau terbentuk dari 3 faktor, yaitu: faktor predisposisi (predisposing factor), yang terwujud dalam pengetahuan, sikap, tradisi, kepercayaan, keyakinan, nilai-nilai, pendidikan, dan sebagainya. Faktor pendukung (enabling factors), yang terwujud dalam lingkungan fisik, tersedia atau tidak tersedianya fasilitas-fasilitas atau, sarana-sarana kesehatan, misalnya puskesmas, obatobatan, alat-alat kontrasepsi, jamban, dan sebagainya. Faktor pendorong (reinforcing factor) yang terwujud dalam sikap dan perilaku tokoh masyarakat, tokoh agama, petugas kesehatan, atau petugas yang lain, yang merupakan kelompok referensi dari perilaku masyarakat.

Menurut Soekanto (2015), faktor yang bersumber dari dalam individu yang dapat mempengaruhi keikutsertaan ibu hamil dalam melakukan senam hamil adalah pendidikan dan pekerjaan. Pendidikan dan pekerjaan juga erat kaitanya dengan pengetahuan ibu hamil. Ibu hamil yang bekerja membantu suami mencukupi nafkah keluarga tidak memiliki banyak waktu untuk mengikuti kegiatan senam hamil. Sedangkan ibu hamil yang tidak bekerja lebih dapat meluangkan waktunya untuk mengikuti senam hamil.

Studi pendahuluan yang peneliti lakukan pada kelas ibu hamil di RS. AR Bunda Kota Prabumulih didapatkan data keikutsertaan ibu hamil dalam kelas senam ibu hamil sebagai berikut: jumlah kelas ibu hamil ada 4 kelas dengan masing-masing kelas beranggotakan 10 ibu hamil, sehingga total ibu hamil yang mengikuti kelas ibu hamil sebanyak 40 orang. Pada bulan Oktober 2018 jumlah peserta senam ibu hamil sebanyak 40 orang dan jumlahnya menurun setiap bulan. Bulan November 2018 jumlah 
peserta sebanyak 38 orang, bulan Desember 2018 sebanyak 32 orang, bulan Januari 2098 sebanyak 29 orang, bulan Februari 2019 sebanyak 24 orang, bulan Maret 2019 sebayak 20 orang dan pada bulan April 2019 jumlah ibu hamil yang mengikuti senam hamil hanya sebanyak 18 ibu hamil (45\%).

Tujuan dari penelitian ini adalah mendeskripsikan pengetahuan ibu hamil tentang senam hamil, pendidikan ibu hamil, pekerjaan ibu hamil dan keikutsertaan ibu hamil dalam melakukan senam hamil, menganalisis hubungan pengetahuan tentang senam hamil, pendidikan ibu hamil dan pekerjaan ibu hamil dengan keikutsertaan ibu hamil dalam melakukan senam hamil, menganalisis secara bersama-sama faktor yang paling berpengaruh terhadap keikutsertaan ibu hamil dalam melakukan senam hamil.

\section{METODE PENELITIAN}

Variabel independent (bebas) yaitu pengetahuan, pendidikan, dan pekerjaan. Variabel dependent (terikat) yaitu adalah keikutsertaan ibu hamil dalam melakukan senam hamil. Penelitian ini merupakan penelitian observasional analitik dengan pendekatan crosssecional. Penelitian ini menggunakan data primer dan data sekunder. Populasi dalam penelitian ini adalah ibu hamil di kelas senam hamil RS. AR Bunda Kota Prabumulih sebanyak40 orang yaitu 22 orang yang sudah tidak mengikuti senam hamil dan 18 orang yang masih mengikuti senam hamil. Teknik pengambilan sampel menggunakan teknik total sampling (Notoatmodjo, 2005). Instrumen penelitian menggunakan kuesioner tentang pengetahuan, tingkat pendidikan, pekerjaan dan keikutsertaan dalam melakukan senam hamil.
Analisa univariat dilakukan untuk mendeskripsikan pengetahuan, tingkat pendidikan, pekerjaan dan keikutsertaan ibu hamil dalam melakukan senam hamil menggunakan distribusi frekuensi. Analisis bivariat dilakukan untuk mengetahui hubungan pengetahuan, tingkat pendidikan, pekerjaan dengan keikutsertaan ibu hamil dalam melakukan senam hamil menggunakan uji Chi Square. Analisis multivariat menggunakan regresi logistik, untuk mengetahui pengaruh bersama-sama semua variabel bebas terhadap variabel terikat (Santjaka. 2015. h. 41-45).

\section{HASIL DAN PEMBAHASAN}

Deskripsi pengetahuan ibu hamil tentang senam hamil tingkat pendidikan ibu hamil, pekerjaan ibu hamil dan keiikutsertaan ibu hamil dalam melakukan senam hamil. Hasil penelitian menunjukkan bahwa pengetahuan ibu hamil tentang senam hamil pada kategori kurang baik sebanyak 24 orang (60\%) lebih banyak daripada kategori baik sebanyak 16 orang (40\%). Tingkat pendidikan dasar ibu hamil sebanyak 27 orang $(67,5 \%)$ lebih banyak daripada yang pendidikan lanjutan yaitu sebanyak 13 orang $(32,5 \%)$. Ibu hamil yang bekerja sebanyak 24 orang (60\%) lebih banyak daripada yang tidak bekerja sebanyak 16 orang $(40 \%)$. Ibu hamil yang tidak mengikuti senam hamil sebanyak 22 orang $(55 \%)$ lebih banyak daripada ibu yang mengikuti senam hamil sebanyak 18 orang $(45 \%)$.

Banyaknya ibu hamil yang mempunyai pengetahuan kurang dapat disebabkan karena banyak ibu hamil yang mempunyai pendidikan dasar. Pendidikan merupakan salah satu faktor yang mempengaruhi pengetahuan. Pengetahuan atau kognitif merupakan domain yang sangat penting dalam membentuk tindakan seseorang. Dengan demikian, pendidikan dan 
pengetahuan yang dimiliki oleh ibu hamil akan mendorong perilaku ibu hamil dalam melakukan senam hamil (Notoatmodjo, 2005. h. 28-34).

Ibu hamil yang bekerja sebagian besar bekerja sebagai buruh. Pekerjaan buruh membuat ibu hamil banyak melewatkan senam hamil pada kelas ibu hamil karena sebagian besar waktu mereka untuk bekerja. Hal ini membuat keikutsertaan ibu hamil dalam mengikuti senam hamil menjadi rendah. Banyaknya ibu hamil yang tidak mengikuti senam hamil dapat di sebabkan karena pengetahuan ibu yang kurang, pendidikan ibu yang rendah dan ibu banyak yang bekerja.

Hubungan pengetahuan ibu hamil tentang senam hamil dengan keikutsertaan ibu hamil dalam melakukan senam hamil

Tabel 1.

Hubungan Pengetahuan Ibu Hamil Tentang Senam Hamil Dengan Keikutsertaan Ibu Hamil Dalam Melakukan Senam Hamil

\begin{tabular}{|c|c|c|c|c|c|c|c|}
\hline \multirow{3}{*}{ Pengetahuan } & \multicolumn{6}{|c|}{ Keikutsertaan Senam Hamil } & \multirow[b]{3}{*}{0,002} \\
\hline & \multicolumn{2}{|c|}{ Ikut } & \multicolumn{2}{|c|}{ Tidak Ikut } & \multicolumn{2}{|c|}{ Total } & \\
\hline & $\mathrm{F}$ & $\%$ & $\mathrm{f}$ & $\%$ & $\mathrm{f}$ & $\%$ & \\
\hline Baik & 12 & 75,0 & 4 & 25,0 & 16 & 100,0 & \\
\hline Kurang Baik & 6 & 25,0 & 18 & 75,0 & 24 & 100,0 & \\
\hline Jumlah & 18 & 45,0 & 22 & 55,0 & 40 & 100,0 & \\
\hline
\end{tabular}

Berdasarkan Tabel 1. di atas dapat diketahui bahwa ibu hamil yang mempunyai pengetahuan baik, sebagian besar mengikuti senam hamil $(75 \%)$. Ibu hamil yang mempunyai pengetahuan kurang baik, sebagian besar tidak mengikuti senam hamil (75\%). Hasil analisis bivariat dengan menggunakan uji chi square diperoleh nilai $p=0,002$, yang artinya ada hubungan antara pengetahuan ibu hamil tentang senam hamil dengan keikutsertaan ibu hamil dalam melakukan senam hamil.

Hasil penelitian ini sesuai dengan teori yang dikembangkan oleh Green, bahwa pengetahuan merupakan faktor predisposisi yang menentukan perilaku seseorang. Pengetahuan merupakan hasil tahu dan ini terjadi setelah seseorang melakukan pengindraan terhadap obyek tertentu. Sebagian besar pengetahuan manusia diperoleh melalui indra mata, telinga. Pengetahuan atau kognitif merupakan domain yang sangat penting untuk terbentuknya tindakan seseorang/overt behavior. Perilaku yang didasari oleh pengetahuan akan lebih bermakna daripada perilaku yang tidak didasari pengetahuan (Notoadmodjo, 2005. h. 28-34). Perilaku yang dimaksud dalam penelitian ini adalah keikutsertaan ibu hamil dalam melakukan senam hamil. 
Tabel 2.

Hubungan Tingkat Pendidikan Ibu Hamil Dengan Keikutsertaan Ibu Hamil Dalam Melakukan Senam Hamil Pada Kelas Ibu Hamil

\begin{tabular}{|c|c|c|c|c|c|c|c|}
\hline \multirow{3}{*}{ Pendidikan } & \multicolumn{6}{|c|}{ Keikutsertaan Senam Hamil } & \multirow{5}{*}{0,005} \\
\hline & \multicolumn{2}{|c|}{ Ikut } & \multicolumn{2}{|c|}{ Tidak Ikut } & \multicolumn{2}{|c|}{ Total } & \\
\hline & $\mathbf{F}$ & $\%$ & $\mathbf{f}$ & $\%$ & $\mathbf{f}$ & $\%$ & \\
\hline Dasar & 8 & 29,6 & 19 & 70,4 & 27 & 100,0 & \\
\hline Lanjutan & 10 & 76,9 & 3 & 23,1 & 13 & 100,0 & \\
\hline Jumlah & 18 & 45,0 & 22 & 55,0 & 40 & 100,0 & \\
\hline
\end{tabular}

Berdasarkan Tabel 2. di atas dapat diketahui bahwa ibu yang mempunyai pendidikan dasar, sebagian besar tidak mengikuti senam hamil $(70,4 \%)$. Ibu yang mempunyai pendidikan lanjutan, sebagian besar mengikuti senam hamil $(76,9 \%)$. Hasil analisis bivariat dengan menggunakan uji chi square diperoleh nilai $p=0,005$ yang artinya ada hubungan tingkat pendidikan ibu hamil dengan keikutsertaan ibu hamil dalam melakukan senamhamil.

Pendidikan merupakan faktor penting yang mempengaruhi perilaku seseorang untuk melakukan tindakan, termasuk tindakan ibu untuk keikutsertaan melakukan senam hamil.pendidikan merupakan salah satu faktor yang mempengaruhi pengetahuan. Pengetahuan melandasi sikap yang akan mendorong perilakunya. Dengan demikian, pendidikan yang dimiliki oleh ibu hamil dapat melandasi sikapnya yang akan mendorong perilaku ibu hamil untuk mengikuti senam hamil.

Seseorang yang mempunyai pendidikan lebih tinggi akan lebih mudah menerima informasi yang disampaikan oleh tenaga kesehatan. Artinya, ia dapat mengadopsi inovasi dengan cepat dibandingkan dengan ibu-ibu berlatar belakangpendidikan rendah yang cenderung sulit untuk mengetahui atau mengikuti informasi yang tersedia dengan keterbatasan pengetahuan (Notoatmodjo, 2005. h. 28-34).

Tabel 3.

Hubungan Pekerjaan Ibu Hamil Dengan Keikutsertaan Ibu Hamil Dalam Melakukan Senamhamil

\begin{tabular}{|c|c|c|c|c|c|c|c|}
\hline \multirow{3}{*}{ Pekerjaan } & \multicolumn{6}{|c|}{ Keikutsertaan Senam Hamil } & \multirow{5}{*}{0,014} \\
\hline & \multicolumn{2}{|c|}{ Ikut } & \multicolumn{2}{|c|}{ Tidak Ikut } & \multicolumn{2}{|c|}{ Total } & \\
\hline & $\mathbf{F}$ & $\%$ & $\mathbf{f}$ & $\%$ & $\mathbf{F}$ & $\%$ & \\
\hline Bekerja & 7 & 29,2 & 17 & 70,8 & 24 & 100,0 & \\
\hline Tidak Bekerja & 11 & 68,8 & 5 & 31,2 & 16 & 100,0 & \\
\hline Jumlah & 18 & 45,0 & 22 & 55,0 & 40 & 100,0 & \\
\hline
\end{tabular}

Berdasarkan Tabel 3. di atas dapat diketahui bahwa ibu yang bekerja, sebagian besar tidak mengikuti senam hamil $(70,8 \%)$ dan bu yang tidak bekerja, sebagian besar mengikuti senam hamil $(68,8 \%)$. Hasil analisis bivariat dengan menggunakan uji chi square diperoleh nilai $p=0,014$ yang artinya ada hubungan antara pekerjaan ibu hamil dengan keikutsertaan ibu hamil dalam melakukan senam hamil.

Ibu hamil yang bekerja memiliki sedikit waktu untuk mengikuti kelas ibu hamil yang salah satu kegiatannya adalah senam hamil. Pekerjaan membuat ibu hamil 
banyak menghabiskan waktu ditempat kerja, sehingga dari hasil penelitian banyak ibu hamil yang bekerja tidak mengikuti senam hamil. Menurut Markum (1991) dalam (Nursalam, 2003 h. 89-102), bekerja umumnya merupakan kegiatan yang menyita waktu. Bekerja bagi ibuibu akan mempunyai pengaruh terhadap kehidupannya sehingga ibu tidak punya banyak waktu untuk mendapatkan informasi. Manusia memerlukan suatu pekerjaan untuk dapat berkembang dan berubah. Seseorang bekerja bertujuan untuk mencapai suatu keadaanyang lebih daripada keadaan sebelumnya. Dengan bekerja seseorang dapat berbuat yang bernilai, bermanfaat dan memperoleh berbagai pengalaman.

Pengaruh pengetahuan, pendidikan dan pekerjaan terhadap keiikutsertaan ibu hamil dalam melakukan senam hamil

Tabel 4.

Hasil Analisis Multivariat

\begin{tabular}{|c|c|c|c|c|c|c|c|c|}
\hline \multirow[t]{2}{*}{ Variabel } & \multirow[t]{2}{*}{ B } & \multirow[t]{2}{*}{ S.E. } & \multirow[t]{2}{*}{ Wald } & \multirow[t]{2}{*}{ df } & \multirow[t]{2}{*}{ Sig. } & \multirow[t]{2}{*}{$\operatorname{Exp}(B)$} & \multicolumn{2}{|c|}{$\begin{array}{c}\text { 95,0\% C.I.for } \\
\text { EXP(B) }\end{array}$} \\
\hline & & & & & & & Lower & Upper \\
\hline Pengetahuan & 1.628 & .859 & 3.598 & 1 & .048 & 5.196 & 1.036 & 21.056 \\
\hline Pendidikan & 1.984 & .973 & 4.158 & 1 & .041 & 7.272 & 1.080 & 48.969 \\
\hline Pekerjaan & 1.825 & .891 & 4.194 & 1 & .041 & 6.201 & 1.082 & 35.551 \\
\hline
\end{tabular}

Tabel 4 menunjukkan bahwa variabel yang mempunyai p-value $<0,05$ dan Exp.(B) $\geq 2$ adalah semua variabel bebas yaitu pengetahuan, pendidikan dan pekerjaan. Variabel pengetahuan dengan p-value 0,048, nilai Exp.(B) 5,196, variabel pendidikan mempunyai $p$-value 0,041, nilai Exp.(B) 7,272 dan variabel pekerjaan dengan p-value 0,041 , nilai Exp.(B)6,201.

Kesimpulannya adalah ada pengaruh pengetahuan, pendidikan dan pekerjaan secara bersama-sama terhadap keikutsertaan ibu hamil dalam melakukan senam hamil. Ibu hamil yang mempunyai pendidikan lanjut akan mengikuti senam hamil 7,2 kali lebih besar dibanding ibu hamil yang berpendidikan dasar. Ibu hamil yang tidak bekerja, akan mengikuti senam hamil 6,2 kali lipat lebih besar dibanding ibu hamil yang bekerja. Ibu hamil yang memiliki pengetahuan baik akan mengikuti senam hamil 4 kali lebih besar dibanding ibu hamil yang mempunyai pendidikan kurang baik. Hal ini berarti keiikutsertaan ibu hamil dalam melakukan senam hamil pada kelas ibu hamil dipengaruhi oleh pengetahuan, pendidikan danpekerjaan.

\section{KESIMPULAN DAN SARAN}

Pengetahuan ibu hamil tentang senam hamil paling banyak pada kategori kurang baik sebanyak 24 orang $(60,0 \%)$, paling banyak responden pada tingkat pendidikan dasar sebanyak 27 orang (67,5\%), paling banyak ibu yang bekerja sebanyak 24 orang $(67,5 \%)$ dan paling banyak ibu hamil yang tidak mengikuti senam hamil sebanyak 22 orang $(55,0 \%)$.

Ada hubungan pengetahuan tentang senam hamil dengan keikutsertaan ibu hamil dalam melakukan senam hamil pada kelas ibu hamil $(\mathrm{p}=0,002)$, ada hubungan tingkat pendidikan tentang senam hamil dengan keikutsertaan ibu hamil dalam melakukan senam hamil pada kelas ibu hamil $(\mathrm{p}=0,005)$, ada hubungan tingkat pekerjaan tentang senam hamil dengan keikutsertaan ibu hamil dalam melakukan senam hamil pada kelas ibu hamil $(\mathrm{p}=0,014)$. 
Ada pengaruh secara bersama-sama pengetahuan, pendidikan dan pekerjaan terhadap keikutsertaan ibu hamil dalam melakukan senam hamil pada kelas ibu hamil.

Diharapkan dapat dipergunakan sebagai referensi untuk penelitian selanjutnya dan meningkatkan kualitas pendidikan kesehatan dalam pelaksanaan asuhan kebidanan pada ibu hamil tentang keikutsertaan ibu hamil dalam melakukan senam hamil.

\section{DAFTAR PUSTAKA}

1. Adriana, Evariny. Mencerdaskan Anak Sejak dalam Kandungan. Edisi Revisi: PT Bhuana Ilmu Populer; 2011.h. 101-124.

2. Andi. Maryunani, \& S. Senam Hamil, Senam Nifas, dan Terapi Musik. Jakarta: Trans Info Media; 2011.h. 29-45.

3. Dewi \& Sunarsih. Asuhan Kebidanan untuk Kehamilan. Yogyakarta: Muha Medika; 2015. h. 97-103.

4. Garcia et al. Gamma band activity in the RAS -intracellular mechanisms; 2014; 1509-1522.

5. Hanifa, W. Ilmu Kebidanan (Edisi 3). Jakarta: Yayasan Bina Pustaka Sarwono .Prawirohardjo; 2015. h. 1015.

6. Jannah, N. Buku Ajar Asuhan Kebidanan Kehamilan. Yogyakarta; 2012. h. 77-102

7. Notoatmodjo, S. Pendidikan dan perilaku kesehatan. Jakarta: Rineka Cipta; 2003. h. 113-117.

8. Notoatmodjo, S. 2005. Pendidikan dan perilaku kesehatan. Edisi revisi. Jakarta: RinekaCipta. 2005. h. 28-34.
9. Nursalam. Konsep \& penerapan metodologi penelitian keperawatan. Jakarta: Salemba2003. h. 89-102.

10. Putri, Shinta. Panduan Senam Hamil Praktis.Yogyakarta: Platinum; 2014. h. 55-61.

11. Puty, I., \& Wibowo, A. Pengaruh Keikutsertaan Senam Hamil Terhadap Kecemasan Primigravida Trimester Ketiga Dalam Menghadapi Persalinan; 201. h. 26-31.

12. Ratnawati \& Rina. Pengaruh Kombinasi Senam Hamil Dengan Relaksasi Swasugesti Terhadap Kesiapan Ibu Hamil Menghadapi Persalinan, 2014. h. 1-11.

13. Santjaka, A. Biostatistik untuk praktisi kesehatan dan mahasiswa kedokteran, kesehatan lingkungan, keperawatan, kebidanan, gizi, kesehatan masyarakat. Purwokerto: Global Internusa; 2015. h. 41-45

14. Wahyuni \& Ni'mah. Manfaat Senam Hamil Untuk Meningkatkan Durasi Tidur Ibu Hamil; Jurnal Kesehatan Masyarakat; 2013. h. 113-120.

15. Wiratna. (SPSS Untuk Penelitian. Yogyakarta: Penerbit Pustaka Baru Press.World Health Organitation. Trend in Maternal Mortalit; 2015. h. $1-5$ 